\title{
ANALYSIS OF SURFACES FOR CHARACTERIZATION OF FUNGAL BURDEN - DOES IT MATTER?
}

\section{CARLA VIEGAS ${ }^{1,2}$, TIAGO FARIA ${ }^{1}$, MÁRCIA MENESES ${ }^{1}$, ELISABETE CAROLINO ${ }^{1}$, SUSANA VIEGAS ${ }^{1,2}$, ANITA QUINTAL GOMES ${ }^{1,3}$, and RAQUEL SABINO ${ }^{1,4}$}

\author{
${ }^{1}$ Polytechnic Institute of Lisbon, Lisbon, Portugal \\ Environment and Health Research Group, Lisbon School of Health Technology \\ ${ }^{2}$ Universidade Nova de Lisboa, Lisbon, Portugal \\ Centro de Investigação em Saúde Pública, Escola Nacional de Saúde Pública \\ ${ }^{3}$ University of Lisbon, Lisbon, Portugal \\ Institute of Molecular Medicine, Faculty of Medicine \\ ${ }^{4}$ National Health Institute Doutor Ricardo Jorge, Lisbon, Portugal \\ Mycology Laboratory
}

\begin{abstract}
Objectives: Mycological contamination of occupational environments can be a result of fungal spores' dispersion in the air and on surfaces. Therefore, it is very important to assess it in both types of the samples. In the present study we assessed fungal contamination in the air and in the surface samples to show relevance of surfaces sampling in complementing the results obtained in the air samples. Material and Methods: In total, 42 settings were assessed by the analysis of air and surfaces samples. The settings were divided into settings with a high fungal load ( 7 poultry farms and 7 pig farms, 3 cork industries, 3 waste management plants, 2 wastewater treatment plants and 1 horse stable) and a low fungal load (10 hospital canteens, 8 college canteens and 1 maternity hospital). In addition to culture-based methods, molecular tools were also applied to detect fungal burden in the settings with a higher fungal load. Results: From the 218 sampling sites, 140 (64.2\%) presented different species in the examined surfaces when compared with the species identified in the air. A positive association in the high fungal load settings was found between the presence of different species in the air and surfaces. Wastewater treatment plants constituted the setting with the highest number of different species between the air and surface. Conclusions: We observed that surfaces sampling and application of molecular tools showed the same efficacy of species detection in high fungal load settings, corroborating the fact that surface sampling is crucial for a correct and complete analysis of occupational scenarios.
\end{abstract}

Key words:

Surface samples, Fungal burden assessment, High fungal load settings, Low fungal load settings, Air samples, Occupational environments

\section{INTRODUCTION}

Recently, concerns about human exposure to microorganisms in indoor environments have been also focused on fungi. Interest in bioaerosol exposure has significantly increased because it is now recognized that exposure to fungal agents is associated with a wide range of adverse health effects with a major impact on public health [1]. However, despite the division of fungi in different biosafety levels [2], as well as the Directive 2000/54/EC [3], referring to the importance of the safety of workers exposed to biological agents, these classifications and documents do not include toxic species that can be present in

This work was financially supported by the Lisbon School of Health Technology - Polytechnic Institute of Lisbon and coordinated by Carla Viegas. Received: January 7, 2015. Accepted: August 27, 2015.

Corresponding author: C. Viegas, Polytechnic Institute of Lisbon, Lisbon School of Health Technology, Environment and Health Research Group, Nations Park, 1990-090 Lisbon, Portugal (e-mail: carla.viegas@estesl.ipl.pt). 
several occupational settings [4]. Additionally, there is no classification that would consider, on the one hand, fungal ability to disseminate and, on the other, the principal intake routes from their spores and metabolites taking into account each occupational setting.

Based on their small size and a large number, fungal spores are classified as bioaerosols. They are always present in the atmosphere and their concentration changes depending on environmental conditions. Production and spore release varies drastically from species to species, influencing its dissemination in the air/surfaces [5].

Aspergillus and Penicillium spores may remain indoors for long periods of time, while Stachybotrys spores diminish their concentration/viability soon after being produced, conditioning interpretation of the results of air samples' cultures [6]. The type of sporulation and spore characteristics (size, density, colony structure and roughness) must also be considered when analyzing fungal contamination of air. Importantly, additional environmental characteristics related to the surfaces, including surface vibrations, smoothness and a role as a substrate [7] may also influence fungal contamination. Cultures in the air samples are usually the only parameters used to assess indoor fungal contamination [8]. According to several authors [9-11], surfaces analysis complements microbiological characterization of the air and is used in order to identify contamination sources. It may also be used to evaluate efficacy of surface cleaning and disinfection procedures.

The number of studies where fungal contamination in workplaces has been characterized both in the air and in the surface samples is very limited [12-19]. In fact, in most of the studies on environmental fungal assessment, the results have been achieved only by air sampling. Because mycological contamination can be a result of fungal spores' dispersion in the air and on the surfaces, it is very important to assess it and evaluate a specific environment based on the results of both types of the samples.
In the present study we assessed fungal contamination in the air and in the samples of surfaces, and showed the relevance of the latter in complementing the results obtained only via analyses of the air samples.

\section{MATERIAL AND METHODS}

\section{Assessed settings}

The sampling of several settings was performed between February 2010 and March 2014. The analyzed settings included 7 poultry farms and 7 pig farms, 3 cork industries, 3 waste management plants, 2 wastewater treatment plants and 1 horse stable. Those settings were chosen because they have high probability of a high fungal load (HFL) [20]. The sampling sites selected for each of the settings mentioned above were chosen based on the amount of time spent by the workers in those places during their occupational activity. In some of those settings, in addition to conventional methods, also molecular methods were applied to detect fungi (Table 1). This approach was performed to overcome some limitations of the culture-based methods and whenever specific species/ strains needed to be detected.

Settings with a low fungal load (LFL) were also analyzed. Those included 10 hospital canteens, 8 college canteens and 1 maternity hospital. All these settings were assessed using conventional methods.

\section{Sample collection}

Conventional methodologies

Two hundred fifty-nine air samples were collected by the use of conventional methods. The amount of the collected air samples ranged from 201 (from pig farms) to 5001 (from hospital wards). The air samples were collected by means of the impaction method with a flow rate of $140 \mathrm{l} / \mathrm{min}$ onto malt extract agar (MEA) supplemented with chloramphenicol $(0.05 \%)$, using the Millipore Air Tester (MerckMillipore, USA). The samplers were placed at a height of $0.6-1.5 \mathrm{~m}$ above the floor, 
Table 1. Collected samples and detected fungal species

\begin{tabular}{|c|c|c|c|c|}
\hline \multirow[b]{2}{*}{ Setting } & \multicolumn{2}{|c|}{ Conventional methods } & \multirow{2}{*}{$\begin{array}{c}\text { Molecular biology } \\
\text { air samples } \\
{[\mathrm{n}]} \\
\end{array}$} & \multirow[b]{2}{*}{ Fungal species (molecular biology) } \\
\hline & $\begin{array}{c}\text { air samples } \\
{[\mathrm{n}]}\end{array}$ & $\begin{array}{c}\text { surface samples } \\
{[\mathrm{n}]}\end{array}$ & & \\
\hline Poultry farms [34] & 28 & 20 & 18 & $\begin{array}{l}\text { A. flavus complex (toxigenic strains) } \\
\text { A. fumigatus complex } \\
\text { Stachybotrys chartarum }\end{array}$ \\
\hline Pig farms [17] & 56 & 48 & - & - \\
\hline $\begin{array}{l}\text { Wastewater treatment } \\
\text { plant (WWTP) [37] }\end{array}$ & 12 & 12 & 11 & $\begin{array}{l}\text { A. flavus complex (toxigenic strains) } \\
\text { A. fumigatus complex } \\
\text { Stachybotrys chartarum }\end{array}$ \\
\hline Waste treatment plant (WTP) [18] & 22 & 22 & 21 & $\begin{array}{l}\text { A. flavus complex (toxigenic strains) } \\
\text { A. fumigatus complex } \\
\text { Stachybotrys chartarum }\end{array}$ \\
\hline Cork industries & 13 & 13 & 12 & $\begin{array}{l}\text { A. fumigatus complex } \\
\text { Penicillium glabrum }\end{array}$ \\
\hline Horse stable & 6 & 3 & - & - \\
\hline Hospital canteen & 50 & 41 & - & - \\
\hline College canteens & 29 & 29 & - & - \\
\hline Maternity hospital & 43 & 43 & - & - \\
\hline Total & 259 & 231 & 44 & \\
\hline
\end{tabular}

approximately at the breathing zone level, and as close as possible to the worker during a normal working day. An outdoor sample was also collected to be used as a reference. Samples of the surfaces (231 samples) were collected by swabbing the surfaces of the same indoor sites, using a $10 \times 10 \mathrm{~cm}^{2}$ stencil disinfected with $70 \%$ alcohol solution between samples according to the International Standard ISO 18593 (2004) [21]. The obtained swabs were then streaked onto MEA.

\section{Molecular methodologies}

Molecular tools were applied to detect fungal presence in 44 samples from the settings with higher fungal loads. The samples collected using both conventional and molecular methodologies are indicated in Table 1. The air samples of 2501 were collected using the impinger Coriolis $\mu$ air sampler (Bertin Technologies, USA), at 300 1/min airflow rate. The samples were collected into $10 \mathrm{ml}$ of sterile phosphate-buffered saline with $0.05 \%$ Triton X-100, and the collection liquid was subsequently used for DNA extraction using the ZR Fungal/Bacterial DNA MiniPrep Kit (Zymo Research, USA), according to the manufacturer's instructions.

\section{Sample preparation and analysis Conventional methodologies}

All the collected samples were incubated at $27^{\circ} \mathrm{C}$ for 5-7 days. After laboratory processing and incubation of the collected samples, quantitative (colony-forming units - $\mathrm{CFU} / \mathrm{m}^{3}$ and $\mathrm{CFU} / \mathrm{m}^{2}$ ) and qualitative results were obtained, with identification of the isolated fungal species. For species identification, microscopic mounts were performed using tease mount or Scotch tape mount and lactophenol cotton blue mount procedures. Morphological Identification was achieved through macro and microscopic characteristics as noted by de Hoog et al. [22]. 
Molecular methodologies

Five milliliters of the collection liquid were centrifuged at $2500 \times \mathrm{g}$ for $10 \mathrm{~min}$, supernatant was removed and DNA was then extracted using the ZR Fungal/Bacterial DNA MiniPrep Kit (Zymo Research, USA), according to the manufacturer's recommendations.

Molecular identification of different species/strains (Table 1) was achieved by the real time polymerase chain reaction (RT-PCR) using the Rotor-Gene 6000 qPCR Detection System (Corbett, Germany). Reactions included 1×iQ Supermix (Bio-Rad), $0.5 \mu \mathrm{M}$ of each primer (Table 2), and $0.375 \mu \mathrm{M}$ of TaqMan probe in a total volume of $20 \mu \mathrm{l}$. Amplification followed a 3-step PCR: 40 cycles with denaturation at $95^{\circ} \mathrm{C}$ for $30 \mathrm{~s}$, annealing at $52^{\circ} \mathrm{C}$ for $30 \mathrm{~s}$, and extension at $72^{\circ} \mathrm{C}$ for $30 \mathrm{~s}$. A non-template control was used in every PCR reaction. As positive controls for the species, DNA samples were obtained from reference strains from the Mycology Laboratory from the National Health Institute of Health Doutor Ricardo Jorge (INSA).

\section{RESULTS}

The samples were collected from 133 (61\%) sampling sites with a HFL and from 85 (39\%) locations with a LFL, from a total of 218 sampling sites (Table 3 ). Of the 218 observed sites, 140 (64.2\%) presented different species in surfaces when compared with the ones identified in the air (Table 3). One hundred and seven out of the 140 sampling sites $(76.4 \%)$ that presented different species were from the group of HFL.

Figure 1 shows distribution of the sampling sites with HFL and LFL, namely the pig farms $(36.1 \%)$, waste treatment plant (WTP) (23.3\%), wastewater treatment plant (WWTP) (13.5\%), poultry farms (15\%), cork industries $(9.8 \%)$, horse stable (2.3\%), maternity hospital (38.8\%), college canteens (31.8\%) and hospital canteens (29.4\%).

In the HFL settings, a positive association was detected between the presence of different species in the air and surfaces $\left(\mathrm{Chi}^{2}\right.$ test, $\mathrm{Chi}_{1}^{2}=32.197, \mathrm{p}=0.000$ and association coefficient $\Phi=-0.384, \mathrm{p}=0.000$ ).

Table 2. Sequence of primers and TaqMan probes used for the real time polymerase chain reaction (PCR)

\begin{tabular}{ll}
\hline \multicolumn{1}{c}{ Targeted fungal species and complexes } & \multicolumn{1}{c}{ Sequence } \\
\hline $\begin{array}{l}\text { P. glabrum complex } \\
\text { primer forward } \\
\text { primer reverse } \\
\text { probe }\end{array}$ & 5'-CATTACTGAGTGAGGGCCCTCT-3' \\
A. flavus complex & 5'-CGTGAGGCGGGAGCA-3' \\
primer forward & 5'-CCAACCTCCCACCCGTG-3' \\
primer reverse & \\
probe & 5'-GTCCAAGCAACAGGCCAAGT-3' \\
A. fumigatus complex & 5'-TCGTGCATGTTGGTGATGGT-3' \\
primer forward & 5'-TGTCTTGATCGGCGCCCG-3' \\
primer reverse & \\
probe & 5'-CGCGTCCGGTCCTCG-3' \\
$\begin{array}{l}\text { S. chartarum } \\
\text { primer forward }\end{array}$ & 5'-CGTGAGGCGGGAGCA-3' \\
primer reverse & 5'-CCAACCTCCCACCCGTG-3' \\
probe & \\
\hline
\end{tabular}


Table 3. Comparison between fungal assessment performed using conventional and molecular methods

\begin{tabular}{|c|c|c|c|c|}
\hline \multirow[b]{2}{*}{ Setting } & \multirow{2}{*}{$\begin{array}{c}\text { Fungal species } \\
\text { (molecular biology) }\end{array}$} & \multicolumn{2}{|c|}{ Conventional methods (species level) } & \multirow{2}{*}{$\begin{array}{c}\text { Molecular biology } \\
\text { air samples } \\
{[n]}\end{array}$} \\
\hline & & $\begin{array}{c}\text { air samples } \\
\text { [n] }\end{array}$ & $\begin{array}{c}\text { surface samples } \\
{[\mathrm{n}]}\end{array}$ & \\
\hline \multirow[t]{3}{*}{ Poultry farms } & $\begin{array}{l}\text { A. flavus complex } \\
\text { (toxigenic strains) }\end{array}$ & 7 & 4 & $\begin{array}{c}4 \\
\text { in } 2 \text { samples wasn't found by } \\
\text { conventional methods }\end{array}$ \\
\hline & A. fumigatus complex & 1 & $\begin{array}{c}1 \\
\text { different sample from air }\end{array}$ & $\begin{array}{c}8 \\
\text { in } 7 \text { samples wasn't found by } \\
\text { conventional methods }\end{array}$ \\
\hline & S. chartarum & 0 & 0 & 0 \\
\hline \multirow[t]{3}{*}{$\begin{array}{l}\text { Wastewater treatment } \\
\text { plant (WWTP) }\end{array}$} & $\begin{array}{l}\text { A. flavus complex } \\
\text { (toxigenic strains) }\end{array}$ & 0 & 0 & 0 \\
\hline & A. fumigatus complex & 1 & $\begin{array}{c}3 \\
\text { different samples from air }\end{array}$ & $\begin{array}{c}7 \\
\text { in } 6 \text { samples wasn't found by } \\
\text { conventional methods }\end{array}$ \\
\hline & S. chartarum & 0 & 0 & 0 \\
\hline \multirow[t]{3}{*}{ Waste management } & $\begin{array}{l}\text { A. flavus complex } \\
\text { (toxigenic strains) }\end{array}$ & 0 & 0 & 0 \\
\hline & A. fumigatus complex & 10 & $\begin{array}{c}12 \\
2 \text { different samples from air }\end{array}$ & $\begin{array}{l}15 \\
\text { in } 1 \text { sample wasn't found by } \\
\text { conventional methods }\end{array}$ \\
\hline & S. chartarum & 0 & 0 & 0 \\
\hline \multirow[t]{2}{*}{ Cork industries } & A. fumigatus complex & 1 & $\begin{array}{c}3 \\
2 \text { different samples from air }\end{array}$ & 0 \\
\hline & P. glabrum complex & 2 & $\begin{array}{c}2 \\
1 \text { different sample from air }\end{array}$ & $\begin{array}{c}10 \\
\text { in } 6 \text { samples wasn't found by } \\
\text { conventional methods }\end{array}$ \\
\hline
\end{tabular}

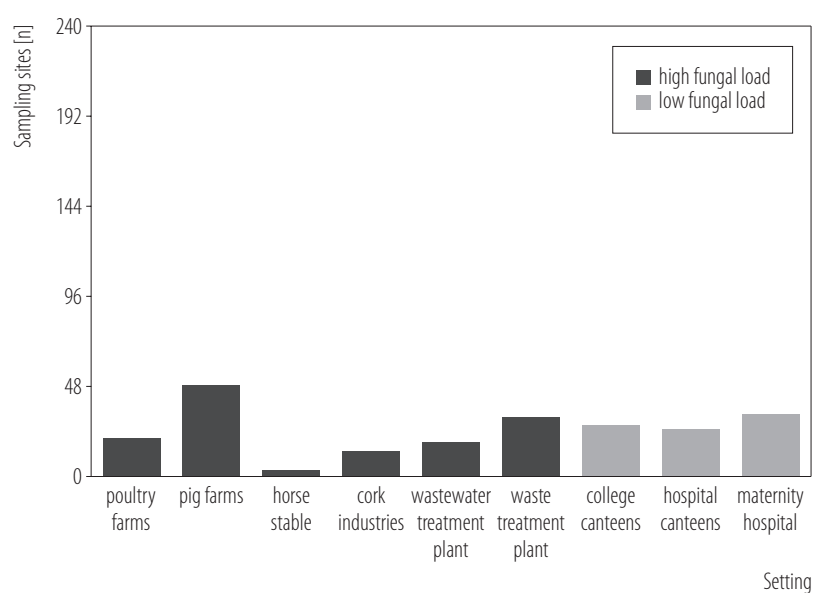

Fig. 1. Sampling sites with a high and a low fungal load
Statistically significant differences were found in the number of different species between the air and surface samples among the sample sites with HFL (Kruskal-Wallis test, $\left.\mathrm{Chi}_{\mathrm{kw}}^{2}(5)=11.403, \mathrm{p}=0.044\right)$. The multiple comparisons of the Kruskal-Wallis test detected significant differences between pig farms $(p=0.027)$, poultry farms $(p=0.033)$ and WWTP $(p=0.012)$ with cork industries sampling sites, with the first ones showing higher values. The setting with the major difference in the number of species found between the air and surface was the WWTP. In the HFL settings 55 species/genera were found only in the samples of surfaces. In the assessed sampling sites, 
the most frequently found genera/species were: Cladosporium sp. (10\%), Penicillium sp. (8.2\%), A. fumigatus complex (9.1\%), A. versicolor complex (7.7\%) and A. flavus complex (5.9\%).

Regarding the surfaces samples from the LFL scenarios, 22 different species/genera were identified only in the samples of surfaces, with Penicillium sp. (13.5\%), Chrysonilia sp. and Chrysosporium sp. (11.5\%) being the most frequently found species.

In the samples that were subjected to both conventional and molecular biology analyses, it was possible to amplify the species that were not detected in the cultures by quantitative PCR (qPCR) (molecular analysis) sequences. A reverse situation was observed in the cork industry, where $A$. fumigatus complex was not detected using molecular methods and it was detected by means of cultural methods (Table 3 ).

\section{DISCUSSION}

Significant fungal exposure occurs in agricultural and industrial industries and may cause occupational respiratory diseases [23]. Fungi can affect human health in a variety of ways resulting in such health outcomes as: infections, allergic reactions (sensitization and immune overreaction), irritations and toxic reactions $[24,25]$.

The lowest observed effect level of 100000 spores $/ \mathrm{m}^{3}$ for non-pathogenic and non-mycotoxin producing fungal species has been proposed in a document with fungal criteria contamination levels based on inflammatory respiratory effects [26]. Several organizations have already proposed guidelines for fungi in indoor environments. However, the applied criteria have been suggested based on problems of indoor fungi assessment and they do not take health effects into consideration [27,28]. Additionally, none of the proposed guidelines mentioned surface fungal assessment. As we observed in some of the analyzed settings in this study, surfaces showed higher diversity in terms of the number of fungal species detected, as well as a higher fungal load, when compared with the air samples.
Analysis of the surface samples, in addition to the air samples, was an important way to optimize sensitivity of surveillance in the areas that are presumed to have low contamination [29] such as hospital environment [14,29,30]. Nevertheless, this technique is not broadly applied, mainly in the HFL settings. This fact limits or even prevents data comparison between the settings. It's important to point out that our main objective of collecting samples, if there was a suspicion of fungal contamination, was to detect, quantify and identify any fungi that might be present [31]. However, in most of the studies where environmental sampling is achieved only through air sampling, data regarding fungal burden are probably underestimated.

The percentage of sampling sites presenting different species in the surfaces than the ones identified in the air (64.2\%), corroborates importance of surface analysis to complement mycological air characterization [9,12-15,32]. Fungal burden differences both in the air and surfaces could be explained by differences in fungal spores dispersion, which varies according to the fungal characteristics and environmental variables [7,9,33,34]. In addition, some species with toxic potential (belonging to $A$. fumigatus complex, $A$. versicolor complex and $A$. flavus complex) were isolated only in the surfaces from the HFL settings, reinforcing the need to assess fungal species present on the surfaces. In the present study, we only compared differences between the air and surfaces in terms of the species level; we did not perform a complete molecular assessment since we applied the tools mentioned above only for specific species/strains targeting. Therefore, we believe that with a broader molecular assessment concerning 2 different sources (air and surfaces), the differences would be higher.

Although in the HFL settings the surface sampling was not widely applied, a positive association in these occupational settings was found between different fungal species present in the air and on the surfaces. Several constraints may explain such results, and some of them are in line with conventional methods limitations, namely growth 
inhibition in the air samples caused by other species because of different growth rates [35,36]. We also observed that pig farms, poultry farms and WWTP presented significant differences in terms of the number of species isolated in the air and in the surface samples, in comparison with cork industries. Such a situation may have occurred due to the overgrowth of Crysonilia sitophilia [37] in both the air and surface samples of this latter setting, simultaneously hindering other species that we were not able to identify. High fungal load settings are occupational contexts with high dust contamination [18,19,38,39] and this environmental parameter can act as a fungi carrier and disseminating agent [40]. Previous research work has presented data that relates high dust contamination to high fungi aerossolization [41,42], corroborating this association. Regarding the WWTP setting, differences regarding the number of species isolated in the air and in the surface samples were the most notorious, probably due to the high levels of moisture that may reduce dust aerossolization and, consequently, also decrease the number of fungal species found in the air [43,44].

Molecular techniques have been often used to measure single species in the air using qPCR techniques [26]. Many studies have shown that concentrations of some species were 10-10 4 times higher when quantified using molecular methods than when assessed by the use of culture methods [45-47]. However, currently, there are no criteria for evaluation of occupational exposure measurements performed with those molecular methods [26]. This has been considered as an obstacle to achieve fungal assessment by the use of these tools. Due to this constraint, simple detection of a specific species/strain using molecular tools is essential to evaluate potential health effects and the risk to the workers posed by the discussed exposure, and it is crucial to overcome conventional methods limitations already addressed in several publications [36,48].

We observed that the surface samples and molecular tools showed the same efficacy of detection in the HFL settings, since both methodologies were not able to identify/detect species/strains in one setting (A. flavus complex identification in surfaces samples from some poultry farms in comparison with air samples and $A$. fumigatus complex detection in cork industry in comparison with data from conventional methods). It is also important to point out that in the LFL it was possible to identify different species in the surface samples from the ones found in the air samples (in $23.6 \%$ of the sampling sites), corroborating importance of application of this resource due to the patients susceptibility (maternity hospital and hospital canteens assessed) and also due to final products safety criteria (food products from hospitals and college canteens assessed).

\section{CONCLUSIONS}

In this study, fungal contamination from several settings was assessed based on the air and surface sampling, proving the relevance of analysis of the latter samples in complementing the results obtained by air sampling. Additionally, we observed that samples of surfaces and molecular tools showed the same efficacy in the HFL settings, corroborating the fact that application of surfaces sampling is crucial not only in hospital wards but also in other occupational scenarios with similar fungal loads.

\section{ACKNOWLEDGMENTS}

The authors are grateful to the Environment and Health Research Group from Lisbon School of Health Technology.

\section{REFERENCES}

1. Méheust D, le Cann P, Reboux G, Millon L, Gangneux J. Indoor fungal contamination: Health risks and measurements methods in hospitals, homes and workplaces. Crit Rev Microbiol. 2014;40:248-60, http://dx.doi.org/10.3109/1040841X. 2013.777687.

2. De Hoog G. Risk assessment of fungi reported from humans and animals. Mycoses. 1996;39:407-17, http://dx.doi. org/10.1111/j.1439-0507.1996.tb00089.x. 
3. Directive 2000/54/EC of the European Parliament and of the Council of 18 September 2000 on the protection of workers from risks related to exposure to biological agents at work (7th individual Directive within the meaning of Article 16(1) of Directive 89/391/EEC). Off J Eur Union L 262, p. 21-45 (Sep 18, 2000).

4. Gutarowska B, Skóra J, Stepien L, Twarużek M, BłajetKosicka A, Otlewska A, et al. Estimation of fungal contamination and mycotoxin production at workplaces in composting plants, tanneries, archives and libraries. World Mycotoxin J. 2014;7(3):345-55, http://dx.doi.org/10.3920/ WMJ2013.1640.

5. Buttner MP, Willeke K, Grinshpun SA. Sampling and analysis of airborne microorganisms. In: Hurst CJ, Knudsen GR, McInerney MJ, Stetzenbach LD, Walter MV, editors. Manual of environmental microbiology. Washington: ASM Press; 1997. p. 629-40.

6. Flannigan B, Miller JD. Health implications of fungi in indoor environments: An overview. In: Samson RA, Flannigan B, Flannigan ME, editors. Health implications of fungi in indoor environments. Amsterdam: Elsevier Science Ltd.; 1994. p. 1-28.

7. Roussel S, Reboux G, Bellanger AP, Sornin S, Grenouillet F, Dalphin JC, et al. Characteristics of dwellings contaminated by mould. J Environ Monit. 2008;10(6):724-9, http://dx.doi. org/10.1039/b718909e.

8. Srikanth P, Sudharsanam S, Steinberg R. Bio-aerosols in indoor environment: Composition, health effects and analysis. Indian J Med Microbiol. 2008;26:302-12, http://dx.doi. org/10.4103/0255-0857.43555.

9. Stetzenbach L, Buttner M, Cruz P. Detection and enumeration of airborne biocontaminants. Curr Opin Biotechnol. 2004;15:170-4, http://dx.doi.org/10.1016/j.copbio. 2004.04.009.

10. Klánová K, Hollerová J. Hospital indoor environment: Screening for micro-organisms and particulate matter. Indoor Built Environ. 2003;12:61-7, http://dx.doi.org/10.1177/ 1420326X03012001010.
11. Faure O, Fricker-Hidalgo H, Lebeau B. Eight-year surveillance of environmental fungal contamination in hospital operating rooms and hematological units. J Hosp Infect. 2002;50(2):155-60, http://dx.doi.org/10.1053/jhin. 2001.1148.

12. Ramos C, Viegas C, Cabo Verde S, Wolterbeek HT, Almeida SM. Characterizing the fungal and bacterial microflora and concentrations in fitness centers. Indoor Built Environ. 2015 May 31:1-11, http://dx.doi.org/10. 1177/1420326X15587954.

13. Lu Z, Lu WZ, Zhang JL. Microorganisms and particles in AHU systems: Measurement and analysis. Build Environ. 2009;44:694-8, http://dx.doi.org/10.1016/j.buildenv. 2008.05.014.

14. Brenier-Pinchart MP, Lebeau B, Mallaret MR. Mobile air-decontamination unit and filamentous fungal load in the hematology ward: How efficient at the low-activity mode? Am J Infect Control. 2009;37:680-2, http://dx.doi. org/10.1016/j.ajic.2008.12.006.

15. Cabo Verde S, Almeida SM, Matos J, Guerreiro D, Meneses M, Faria T, et al. Microbiological assessment of indoor air quality at different hospital sites. Res Microbiol. 2015;166(7):557-63, http://dx.doi.org/10.1016/j.resmic. 2015.03.004.

16. Sabino R, Faísca VM, Carolino E, Veríssimo C, Viegas C. Occupational exposure to Aspergillus by swine and poultry farm workers in Portugal. J Toxicol Environ Health A. 2012;75:1381-91, http://dx.doi.org/10.1080/15287 394.2012.721170.

17. Pinheiro C, Viegas C, Viegas S, Veríssimo C, Brandão J, Macedo M. Indoor air quality in Portuguese archives: A snapshot on exposure levels. J Toxicol Environ Health A. 2012;75:1359-70, http://dx.doi.org/10.1080/15287 394.2012.721168.

18. Viegas C, Carolino E, Sabino R, Viegas S, Veríssimo C. Fungal contamination in swine: A potential occupational health threat. J Toxicol Environ Health A. 2013;76(4-5):272-80, http://dx.doi.org/10.1080/15287394.2013.757205. 
19. Viegas C, Quintal Gomes A, Abegão J, Sabino R, Graça T, Viegas S. Assessment of fungal contamination in waste sorting and incineration - Case study in Portugal. J Toxicol Environ Health A. 2014:77(1-3):57-68, http://dx.doi.org/10. 1080/15287394.2014.865583.

20. European Agency for Safety and Health at Work. EUOSHA Annual report 2007: Bringing safety and health closer to European workers. Luxembourg: Office for Official Publications of the European Communities; 2007.

21. ISO 18593:2004(E). Microbiology of food and animal feeding stuffs - Horizontal methods for sampling techniques from surfaces using contact plates and swabs. Geneva: International Organization for Standardization; 2004.

22. De Hoog C, Guarro J, Gené G, Figueras M. Atlas of clinical fungi. 2 nd ed. Utrecht: Centraalbureau voor Schimmelcultures; 2000.

23. Reboux G, Roussel S, Grenouillet F. [Fungi in agricultural environment]. J Mycol Med. 2006;16:248-62, http://dx.doi. org/10.1016/j.mycmed.2006.09.003. French.

24. Fischer G, Dott W. Relevance of airborne fungi and their secondary metabolites for environmental, occupational and indoor hygiene. Arch Microbiol. 2003;179:75-82.

25. McGinnis MR. Pathogenesis of indoor fungal diseases. Med Mycol. 2004;42:107-17, http://dx.doi.org/10.1080/136937804 10001661473.

26. Eduard W. The Nordic Expert Group for Criteria Documentation of Health Risks from Chemicals. 139. Fungal spores. Stockholm: National Institute for Working Life; 2006 [cited 2014 Dec 15]. Available at: http:/gupea.ub.gu.se/dspace/ bitstream/2077/4359/1/ah2006_21.pdf.

27. Rao CY, Burge HA, Chang JC. Review of quantitative standards and guidelines for fungi in indoor air. J Air Waste Manage Assoc. 1996;46:899-908, http://dx.doi.org/10.1080/ 10473289.1996.10467526.

28. World Health Organization guidelines for indoor air quality: Dampness and mould. Geneva: The Organization; 2009.

29. Gangneux JP, Bousseau A, Cornillet A, Kauffmann-Lacroix C. [Control of fungal environmental risk in French hospitals]. J Mycol Med. 2006;16:204-11, http://dx.doi. org/10.1016/j.mycmed.2006.10.002. French.

30. Sabino R, Veríssimo C, Parada H, Brandão J, Viegas C, Carolino E, et al. Molecular screening of 246 Portuguese Aspergillus isolates among different clinical and environmental sources. Med Mycol. 2014;52:517-27, http://dx.doi. org/10.1093/mmy/myu006.

31. Portnoy JM, Barnes CS, Kennedy K. Sampling for indoor fungi. J Allergy Clin Immunol. 2004;113:189-98, http:// dx.doi.org/10.1016/j.jaci.2003.11.021.

32. Viegas C, Alves C, Carolino E, Pinheiro C, Rosado L, SilvaSantos C. Assessment of fungal contamination in a group of Lisbon's gymnasiums with a swimming pool. Ital J Occup Environ Hyg. 2011;2(1):15-20.

33. Kemp PC, Neumeister-Kemp HG, Esposito B, Lysek G, Murray F. Changes in airborne fungi from the outdoors to indoor air; large HVAC systems in nonproblem buildings in 2 different climates. Am Ind Hyg Assoc J. 2003;64: 269-75, http://dx.doi.org/10.1080/15428110308984817.

34. Górny RL. Filamentous microorganisms and their fragments in indoor air - A review. Ann Agric Environ Med. 2004;11:185-97.

35. Zorman T, Jersek B. Assessment of bioaerosol concentrations in different indoor environments. Indoor Built Environ. 2008;17(2):155-63, http://dx.doi. org/10.1177/1420326X08089251.

36. Viegas C, Malta-Vacas J, Sabino R, Viegas S, Veríssimo C. Accessing indoor fungal contamination using conventional and molecular methods in Portuguese poultries. Environ Monit Assess. 2014;186(3):1951-9, http://dx.doi.org/10.1007/ s10661-013-3509-4.

37. Francuz B, Year H, Geraut L, Bensefa-Colas L, Nghiem ZH, Choudat D. Occupational asthma induced by Chrysonilia sitophila in a worker exposed to coffee grounds. Clin Vaccine Immunol. 2010;17(10):1645-6, http://dx.doi.org/10.1128/ CVI.00134-10.

38. Viegas C, Carolino E, Malta-Vacas J, Sabino R, Viegas S, Veríssimo C. Fungal contamination of poultry litter: A public 
health problem. J Toxicol Environ Health A. 2012;75(2223):1341-50, http://dx.doi.org/10.1080/15287394.2012.721165.

39. Viegas C, Almeida-Silva M, Gomes AQ, Wolterbeek HT, Almeida SM. Fungal contamination assessment in Portuguese elderly care centers. J Toxicol Environ Health A. 2014;77 (1-3):14-23, http://dx.doi.org/10.1080/15287394.2014.861336.

40. Raulf M, Buters J, Chapman M, Cecchi L, de Blay F, Doekes G, et al. Monitoring of occupational and environmental aeroallergens - EAACI position paper. Allergy. 2014;69(10):1280-99, http://dx.doi.org/10.1111/all.12456.

41. Crook B, Easterbrook A, Stagg S. Exposure to dust and bioaerosols in poultry farming. Summary of observations and data. London: Health and Safety Executive; 2008.

42. Millner PD. Bioaerosols associated with animal production operations. Bioresource Technol. 2009;100:5379-85, http:// dx.doi.org/10.1016/j.biortech.2009.03.026.

43. Zhu K, Tan R, Ng WK, Shen S, Zhou Q, Heng P. Analysis of the influence of relative humidity on the moisture sorption of particles and the aerosolization process in a dry powder inhaler. J Aerosol Sci. 2008;39:510-24, http://dx.doi. org/10.1016/j.jaerosci.2008.02.003.

44. Lin ZJ, Tao J, Chai FH, Fan SJ, Yue JH, Zhu LH, et al. Impact of relative humidity and particles number size distribution on aerosol light extinction in the urban area of Guangzhou. Atmos Chem Phys. 2013;13:1115-28, http:// dx.doi.org/10.5194/acp-13-1115-2013.

45. Meklin T, Haugland RA, Reponen T. Quantitative PCR analysis of house dust can reveal abnormal mold conditions. J Environ Monit. 2004;6:615-20, http://dx.doi.org/10.1039/ b400250d.

46. Yamamoto N, Kimura M, Matsuki H, Yanagisawa Y. Optimization of a real-time PCR assay to quantitate airborne fungi collected on a gelatin filter. J Biosci Bioeng. 2010;109:83-8, http://dx.doi.org/10.1016/j.jbiosc.2009.06.015.

47. Zeng QY, Westermark SO, Rasmuson-Lestander A, Wang XR. Detection and quantification of Wallemia sebi in aerosols by real-time PCR, conventional PCR, and cultivation. Appl Environ Microbiol. 2004;70:7295-302, http:// dx.doi.org/10.1128/AEM.70.12.7295-7302.2004.

48. Viegas C, Malta-Vacas J, Sabino R. Molecular biology versus conventional methods - Complementary methodologies to understand occupational exposure to fungi. Proceeding of the 8th International Symposium on Occupational Safety and Hygiene; 2012 Feb 9-10; Guimarães, Portugal. Guimarães: Minho University; 2012. p. 478-9.

This work is available in Open Access model and licensed under a Creative Commons Attribution-NonCommercial 3.0 Poland License - http://creativecommons.org/ licenses/by-nc/3.0/pl/deed.en. 